\title{
A rapid response of testate amoebae and vegetation to inundation of a kettle hole mire
}

\author{
Mariusz Lamentowicz • Milena Obremska
}

Received: 7 November 2008/Accepted: 12 May 2009/Published online: 30 May 2009

(C) Springer Science+Business Media B.V. 2009

\begin{abstract}
Our palaeoecological study covers 73 years of history (1929-2002) of a kettle hole peatland inundated by water from a nearby, dammed lake. Testate amoebae, pollen and non-pollen palynomorphs (NPPs) were used to track the shift to wetter conditions in the peatland. Lead-210 was used to try and construct the chronology. We investigated how peatland testate amoebae communities changed since the damming of a nearby river. Furthermore, we evaluated how rapidly local vegetation responded to the increase in wetness, and how vegetation changes correlated with shifts in testate amoebae and NPPs. The Mukrza kettle hole provided palaeoecological
\end{abstract}

M. Lamentowicz $(\bowtie) \cdot$ M. Obremska

Department of Biogeography and Palaeoecology, Faculty of Geographical and Geological Sciences, Adam Mickiewicz University, Dziegielowa 27, 61-680 Poznań, Poland

e-mail: mariuszl@amu.edu.pl

M. Lamentowicz

Ecosystem Boundaries Research Unit, Wetlands Research Group, Swiss Federal Research Institute (WSL), Station 2, 1015 Lausanne, Switzerland

M. Lamentowicz

Laboratoire des Systèmes Écologiques, École Polytechnique Fédérale de Lausanne (EPFL), Station 2, 1015 Lausanne, Switzerland

\section{Lamentowicz}

Laboratory of Soil Biology, Institute of Biology, University of Neuchâtel, 2009 Neuchâtel, Switzerland evidence of trophic state and hydrological changes since the lake filled with water in 1929. Three stages of development were revealed. The first two were associated with initial inundation, and the third was related to Sphagnum expansion and acidification. Quantitative reconstruction of groundwater level and $\mathrm{pH}$, inferred using testate amoebae, confirmed our hypotheses about changes in hydrology and trophic state. Subfossil desmid remains lend qualitative support to the reconstruction. The ecology of several testate amoeba taxa is discussed in the context of succession and population establishment. There was complete species replacement since the time of inundation. Our investigation has two important applied aspects: (1) it enables prediction of the response of peatlands to a rise in water table on restored sites; and (2) it provides analogues for palaeoclimatological studies. The history of the $\mathrm{Mu}-$ krza mire is an example of how palaeoecological studies can be used to assess the degree of change in peatlands transformed by human activities.

Keywords Peatland S Sphagnum .

Human impact · Damming · Testate amoebae . Pollen $\cdot$ Wet shift

\section{Introduction}

Testate amoebae are extremely useful in research on the hydrology and palaeohydrology of peatlands (Booth 2007; Charman et al. 2002; Lamentowicz and 
Mitchell 2005b; Mitchell et al. 2008a, b). They have been used widely in palaeoecology, often in combination with other environmental proxies such as pollen and plant macrofossils (Blundell et al. 2008; Booth et al. 2008; Charman and Blundell 2007; Escobar et al. 2008; Lamentowicz et al. 2008b; Mitchell et al. 2008a, b; van der Linden et al. 2008). Existing quantitative palaeohydrological reconstructions are based on transfer functions that have been constructed for various regions of the world (Booth et al. 2008; Charman and Blundell 2007; Lamentowicz et al. 2008a; Lamentowicz and Mitchell 2005a; Payne and Mitchell 2007).

Peatland organisms react rapidly to water table increases (Weltzin et al. 2001). Wet shifts have been recognized in many palaeohydrological records across Europe (Amesbury et al. 2008; Hendon et al. 2001; Langdon and Barber 2005; Mauquoy et al. 2002; Roos-Barraclough et al. 2004; Sillasoo et al. 2007; Wilmshurst et al. 2002).

Peatlands are very sensitive to various human activities. Most of the Polish and European peatlands were transformed over the last 300 years (Tobolski 2003). A majority of them were exploited and damaged by human-mediated decreases in the water table (Joosten and Clarke 2002). The most important effect of such changes was associated with lowered water level and increased peat decomposition (Gorham and Rochefort 2003). The acrotelm was artificially deepened, which led to the disappearance of peat-forming plant species (Rydin and Jeglum 2006). Such changes have important implications for carbon turnover, as $\mathrm{CO}_{2}$ is released to the atmosphere from peatlands that formerly played a role as carbon sinks (Belyea and Malmer 2004; Charman 2002; LaggounDéfarge et al. 2008). Knowledge of processes in dried and rewetted peatlands is very important to understand wetland ecosystems, and is an important tool in conservation (Heathwaite and Göttlich 1993).

Most palaeoecological records of testate amoebae from peatlands have no associated historical background information. For example, the response of testate amoebae to water table fluctuation has not been tested against known wet shifts triggered by human activities. Hydrological fluctuations in peatlands may be caused by natural (i.e. climatic) phenomena or anthropogenic disturbances (Charman 2002). Palaeoecological data from sites where the timing of the disturbance is well known are particularly useful in that they enable the investigator to evaluate ecosystem changes in response to a known, dated perturbation. It is then possible to assess how quickly protozoa react to abrupt wet shifts, or adjust to rapidly changing environmental conditions. Historically documented hydrological changes allow us to test transfer functions that employ testate amoebae as hydrologic proxies, and to further evaluate the utility of testate amoebae as environmental indicators.

The aims of this study were: (1) to determine how testate amoebae communities changed since artificial inundation of a peatland, which resulted from damming of a nearby river, (2) to assess how rapidly local vegetation responded to the increase in wetness and how such vegetation changes correlate with shifts in testate amoebae and NPPs, and (3) to evaluate the degree of change in the impacted peatland.

Study site

The study site is located in northern Poland, in the large Tuchola Forest (Bory Tucholskie) (Fig. 1). The forest is dominated by Scots pines (Pinus sylvestris) that grow on the outwash plain created during the Pomeranian phase of the last Vistulian (Weichselian) glaciation. The sandy sediment that underlies many lakes and peatlands in the Tuchola Forest is very permeable, so hydrological manipulations may affect them (Kowalewski 2003).

The present plant cover of the peatland is composed mostly of Sphagnum riparium, S. fallax and $S$. fimbriatum, accompanied by some vascular plants: Vaccinium oxycoccos, Drosera rotundifolia and Eriophorum vaginatum. The peatland margins are dominated by Calla palustris, Typha latifolia, Lysimachia vulgaris, Juncus effusus, Carex rostrata, Solanum dulcamara, and Thelypteris palustris. Dwarf pine trees are scattered on the peatland surface, while Populus tremula, Alnus glutinosa and Frangula alnus grow at the edge of the peatland.

The Mukrza kettle hole mire lies in a small (1 ha), but relatively deep basin ( $>15 \mathrm{~m}$ depth). The crosssection (13 cores) shows the site's stratigraphy (Fig. 2). The maximum cored depth was $14.25 \mathrm{~m}$, but did not reach underlying mineral material, which in other cores was composed of sandur sands. In its initial phase, the basin was filled with water, which is documented by the presence of lake sediments. Next, telmatic conditions are recorded by the presence of true mosses (Bryopsida). The central part of the 

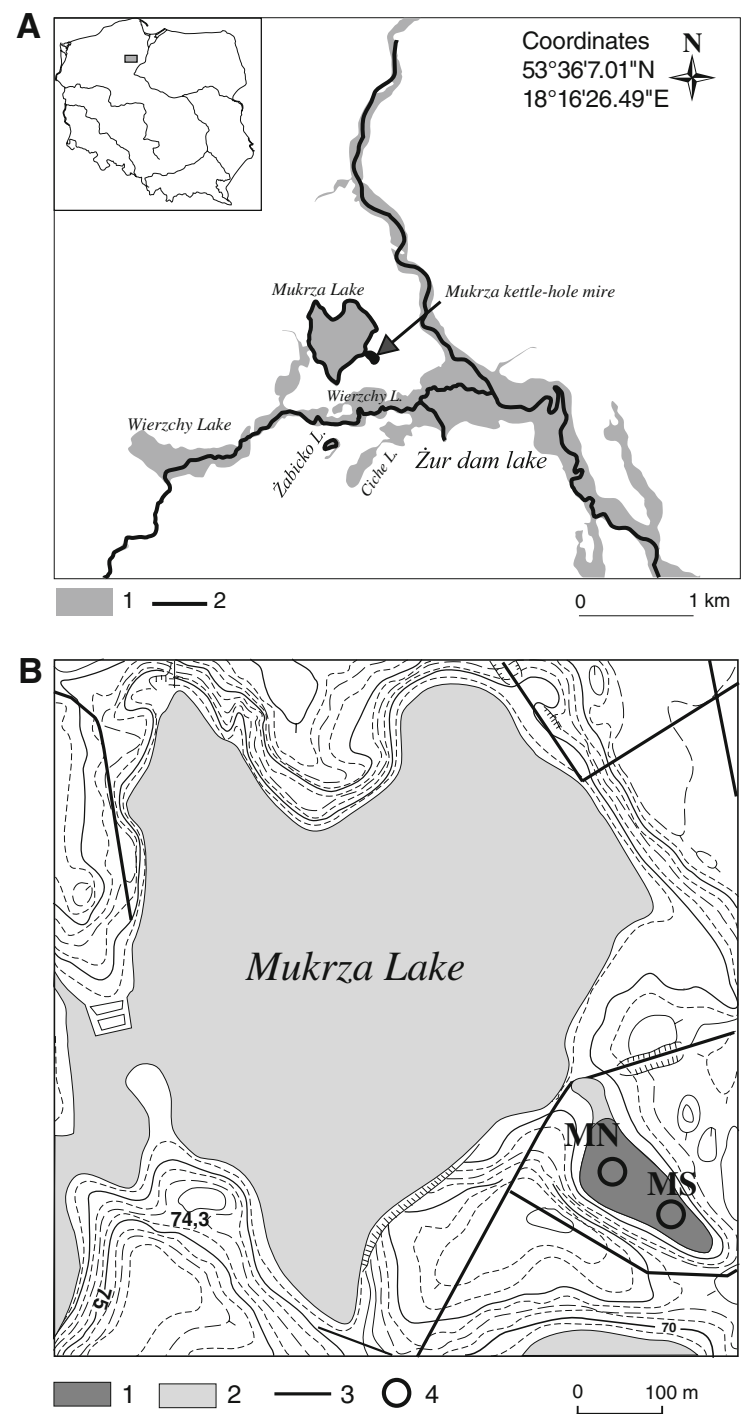

Fig. 1 Location of Mukrza lake. a Żur dam lake: 1 open water of Żur dam lake, 2 former river channel. b Mukrza lake with studied peatlands: 1 peatland, 2 open water, 3 path, 4 sampling sites

peatland (up to $7 \mathrm{~m}$ ) is filled with a 'plug' composed of peat mosses (Sphagnopsida). Sphagnum peat does not contact the bottom of the basin, being isolated from it by true moss and herbaceous peat. There is a floating Sphagnum mat in the northern part of the mire, which has been disappearing gradually to the south.

\section{Methods}

A 50-cm-long core (MS) (Figs. 2, 3) was sampled from the Sphagnum mat that floats over the former surface of the peatland. Seven bulk peat samples were taken for ${ }^{210} \mathrm{~Pb}$ dating from core MS in 2002. Samples were dried at $105^{\circ} \mathrm{C}$ and then milled and homogenized. For polonium measurement, $1.2 \mathrm{~g}$ of material was used. Activity of ${ }^{210} \mathrm{Po}$ was measured by alpha spectrometry and ${ }^{210} \mathrm{~Pb}$ was estimated from ${ }^{210}$ Po activity, assuming the two radioisotopes were in isotopic equilibrium. The polonium was extracted from the samples with concentrated acids according to Flynn (1968). The CRS (Appleby 2001) model was used for ${ }^{210} \mathrm{~Pb}$ age calculation. Measurements were carried out at the Institute of Geological Sciences of the Polish Academy of Sciences in Warsaw.

Samples $\left(1 \mathrm{~cm}^{3}\right)$ for pollen analysis were taken every $1 \mathrm{~cm}$. Sample preparation followed standard laboratory protocols (Berglund and Ralska-Jasiewiczowa 1986). Before acetolysis, the peat material was boiled for $10 \mathrm{~min}$ in $10 \% \mathrm{KOH}$. The residue was then sieved over a $200 \mu \mathrm{m}$ mesh. Pollen of trees and shrubs (arboreal pollen, AP) was counted to a total of 500, at $400 \times$ magnification. Pollen of aquatic and telmatic plants was excluded from the percentage calculation. Non-pollen palynomorphs (NPPs) Pediastrum, Botryococcus, Coelastrum, Tetraedron and Scenedesmus, spines of Utricularia, and charcoal were also counted. The identification of spores was based on the available literature (Erdtman et al. 1961; Faegri and Iversen 1989; Jankovská and Komárek 2000; Komárek and Jankovská 2001; Moore et al. 1991).

Samples for analysis of testate amoebae and other NPPs were taken at 2-cm intervals. Samples were prepared according to the sieving and back-sieving procedure described by Hendon and Charman (1997). Testate amoebae were identified and counted to a total of 150 individuals per sample at a magnification of $200-400 \times$. Identification was based on the available literature (Charman et al. 2000; Clarke 2003; Grospietsch 1958; Ogden and Hedley 1980).

To reconstruct quantitatively the water table depth and $\mathrm{pH}$ in the mire, we applied a training set consisting of 123 surface samples taken from natural Sphagnum mires in Pomerania (Lamentowicz et al. 2008c). The CANOCO program (ter Braak and Šmilauer 1998) was used for ordination analysis of the fossil testate amoebae data. Detrended correspondence analysis with square-root transformation was applied to visualize better the shift in testate amoebae communities. Other statistics were calculated in R-package (R Development Core Team 2006). 
Fig. 2 Geological profile of Mukrza kettle-hole mire. MS—monolith described for this study

Fig. 3 Peat monolith MS sampled for the study
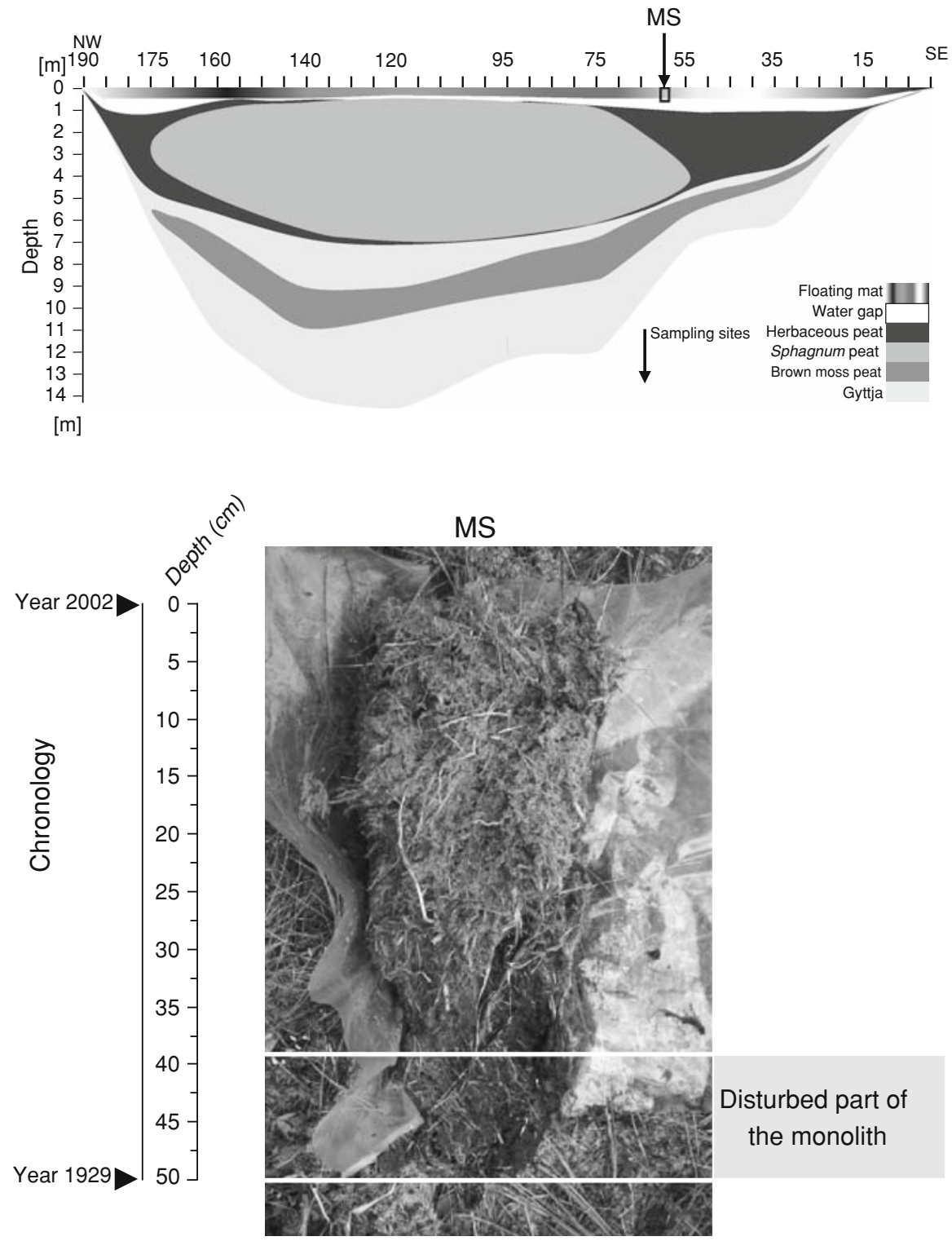

Stratigraphic diagrams were generated with Tilia Graph (Grimm 1992) and C2 (Juggins 2003). Zonation was constructed with the CONISS program (Grimm 1987) included in the Tilia-Graph package.

\section{Results}

\section{Chronology}

Lead-210 results from core MS displayed a nonmonotonic decline in activity with depth, and large uncertainties (Table 1). Consequently, the data were not used to develop a core chronology. Lead dating of recent peat has been described in the literature (e.g. Appleby et al. 1997; Shotyk et al. 1996; Turetsky et al. 2004), but can be difficult or impossible (Payne and Pates 2009), especially if the peat has been disturbed. Dating problems may also occur if groundwater levels cause movement of the lead isotopes in peat profiles. This is the most probable explanation in Mukrza because samples from another core from this peatland, analysed the same way, provided satisfactory results. Because we were unable to construct an age-depth 
Table 1 Results of lead dating of MS monolith

\begin{tabular}{|c|c|c|c|c|}
\hline Depth $[\mathrm{cm}]$ & Activity (Bq/g) & Error $(\mathrm{Bq} / \mathrm{g})$ & Age ${ }^{210} \mathrm{~Pb}$ (years) & Error (years) \\
\hline 1 & 0.28 & 0.01 & 0 & 1.8 \\
\hline 5 & 0.19 & 0.007 & 14 & 3 \\
\hline 15 & 0.128 & 0.005 & 40 & 10 \\
\hline 19 & 0.12 & 0.008 & 50 & 20 \\
\hline 23 & 0.0966 & 0.0057 & 40 & 40 \\
\hline 29 & 0.10 & 0.004 & 75 & 45 \\
\hline 35 & 0.073 & 0.005 & 75 & 80 \\
\hline
\end{tabular}

model for the core, we relied on two horizons of known age for dating, 1929, when the Wda River was dammed, and 2002, the date the core was collected.

Pollen and non-pollen palynomorphs (NPPs)

Domination of Pinus (up to $75 \%$ ) pollen with a very low percentage of other tree taxa was typical for the MS core (Fig. 4). Pollen zones were determined as follows:
M-po-1 $(50-38 \mathrm{~cm})$

This zone is characterized by a very high percentage of herbaceous plants (20\%), including cereals (5\%). Utricularia (represented by pollen or spines), Potamogeton, and Lemna. Cyperaceae, Carex type, Typha latifolia achieve the highest percentage among telmatophytes. Sparganium sp. and Calla palustris occur in small numbers.

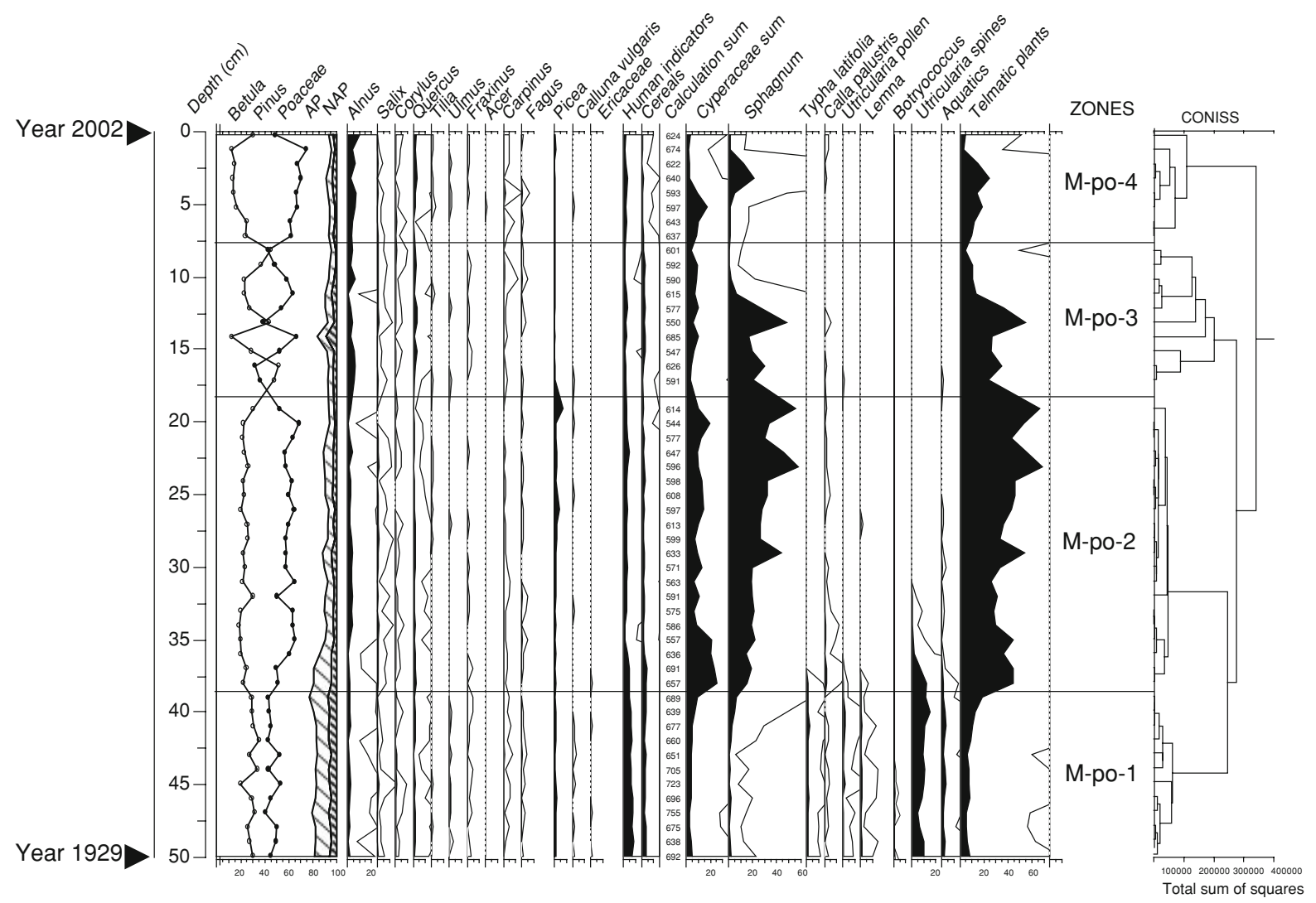

Fig. 4 Pollen percentage diagram with zonation 
M-po-2 $(38-18 \mathrm{~cm})$

Increase in Pinus pollen, peak of Picea (7.3\%). Utricularia, Potamogeton, and Lemna gradually disappear. Hydrophytes are represented by Nymphaea. Sphagnum spores are very numerous, together with Carex and Cyperaceae. Calla palustris is still present.

M-po-3 (18-7.5 cm)

Spruce percentage decreases, simultaneous with alder and oak increases. There is a gradual decrease in Sphagnum and telmatic plants, and stable Cyperaceae.

M-po-4 $(7.5-0 \mathrm{~cm})$

Betula decreases and Pinus increases. Telmatophytes decrease and hydrophytes disappear. Carex pollen and Sphagnum spores account for the highest percentages. Calla palustris pollen is very rare.
Testate amoebae and NPPs

Testate amoebae and NPP zones represent hydrological and trophic state stages in the peatland development after its inundation (Fig. 5). Results of detrended correspondence analysis (DCA) are shown in Fig. 6.

\section{M-ta-1 (50-36 cm)}

This zone is dominated mainly by hygrophilous testate amoebae, e.g. Difflugia rubescens, Arcella gibbosa and Difflugia acuminata. Centropyxis aculeata, C. ecornis and Difflugia urceolata represent relatively high $\mathrm{pH}$. The highest reconstructed $\mathrm{pH}$ was 7, followed by a decrease over time. Presence of Trigonopyxis arcula, Phryganella acropodia and Difflugia pulex, which are regarded as dry indicators, might be the result of test re-deposition from the former peatland surface. However, identification of $P$. acropodia is sometimes problematic (Charman et al. 2000), and the ecology of D. pulex is still not

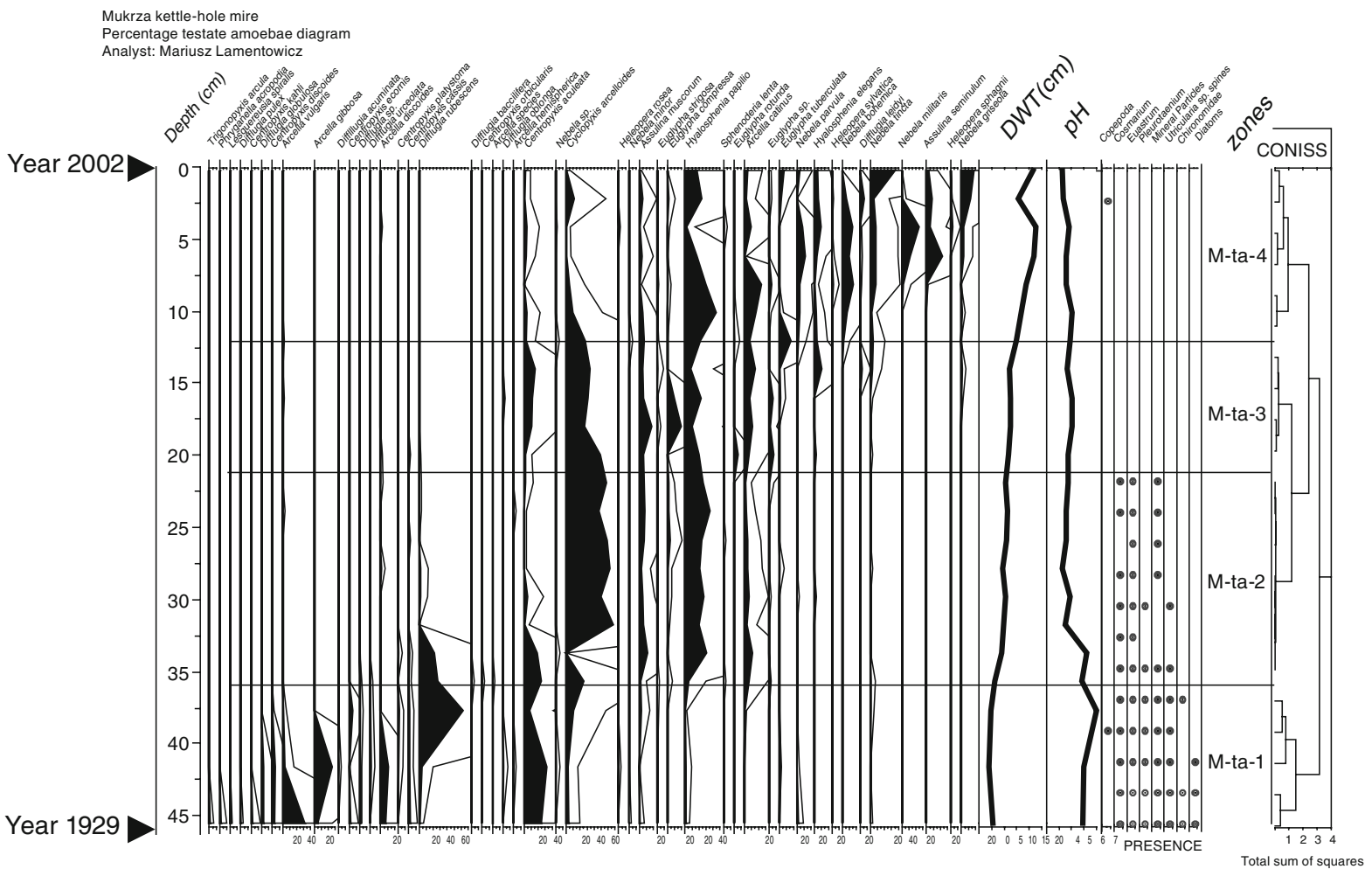

Fig. 5 Testate amoebae percentage diagram with zonation. Species are sorted by weighted average 
well known (Mitchell et al. 2008a, b). Chironomidae remains are recorded in this zone. The desmids Cosmarium, Pleurotaenium and Euastrum, very rare in the Quaternary deposits, reveal very wet conditions. Presence of mineral particles reflects soil erosion. The distance to water table (DWT) remains at $0 \mathrm{~cm}$, which explains the presence of open-water indicators.

M-ta-2 $(36-21 \mathrm{~cm})$

Chironomidae and diatoms are not present in this zone. Pleurotaenium is still present at the bottom of the zone, whereas Cosmarium and Euastrum are recorded throughout the zone. Mineral material is still present. Difflugia rubescens and Centropyxis aculeata decline abruptly between 37 and $32 \mathrm{~cm}$. Initially present in low percentages, Nebela tincta appears. Cyclopyxis arcelloides, Hyalosphenia papilio and Assulina muscorum suggest terrestrial and acidic conditions. Inferred $\mathrm{pH}$ decreases abruptly from 6 to about 4. Sphagnum remains are more common.

$M-t a-3(21-12 \mathrm{~cm})$

Testate amoebae (Arcella catinus, Assulina muscorum) indicate a gradual water table decrease. Increased percentage of Centropyxis aculeata suggests slight eutrophication. There are no desmids, diatoms or mineral particles in this zone.

M-ta-4 $(12-0 \mathrm{~cm})$

Ground water gradually decreases to a maximum of $17.9 \mathrm{~cm}$, indicated by a testate amoebae community dominated by Assulina seminulum, Nebela militaris, and Physochila (Nebela) griseola. Hyalosphenia papilio is a dominant taxon. Inferred $\mathrm{pH}$ varies around 4.

\section{Ordination}

Detrended correspondence analysis also confirmed the above-described zones that characterize the testate amoebae communities. Axis 1 represents moisture and trophic state. Reconstructed values of DWT and pH are correlated (Fig. 7), therefore the first axis of DCA might be interpreted as the gradient of wetness and trophic state. The line linking the samples (Fig. 6a) shows a path of succession linking the particular assemblages. The DCA plot shows a complete replacement of species over time. Species structure in Fig. $6 \mathrm{~b}$ shows testate amoebae that are wet indicators on the right side of the diagram, and dry indicators on the left side. The transition along the gradient is rather gradual. Sample 22 included an unusual species assemblage (Difflugia pulex, Phryganella acropodia and Trigonopyxis arcula), probably transported from the former peatland surface, and was interpreted as an outlier. Lesquereusia spiralis is the taxon that is indicative of a flooded peatland surface. Two stages of the inundation are visible. The first one is represented by such taxa as Arcella vulgaris and Centropyxis ecornis, and the second consists of telmatic indicators like Difflugia rubescens and D. urceolata. An assemblage dominated by Hyalosphenia papilio and Assulina muscorum, representing acidification and a decreasing trend in water table level, is well separated in the DCA plot.

\section{Discussion}

The present Mukrza peatland is an example of a peatforming environment created by human activities. Our intention was to assess how the peatland responded to the well-known shift to wetter conditions caused by the Wda River damming. Artificial inundation led to a stable groundwater level, sustained by the Żur dam. This provided a unique opportunity to understand the local succession pattern under stable hydrological conditions. The material from Mukrza is exceptional because the exact time of the hydrologic change is known. The result of damming is even visible in the geological crosssection in the form of a 'new' peat stratum that formed over the former peatland surface (Fig. 2). Our detailed palaeoenvironmental study provides precise information about the pattern and timing of changes that took place from 1929 to 2002.

\section{Pattern and timing of changes}

We reconstructed the complete hydrosere development that occurred under artificially wet conditions over 73 years. As much as $50 \mathrm{~cm}$ of peat accumulated since the dam was constructed, indicating the mean peat accumulation rate was very high $\left(6.8 \mathrm{~mm} \mathrm{a}^{-1}\right)$. 

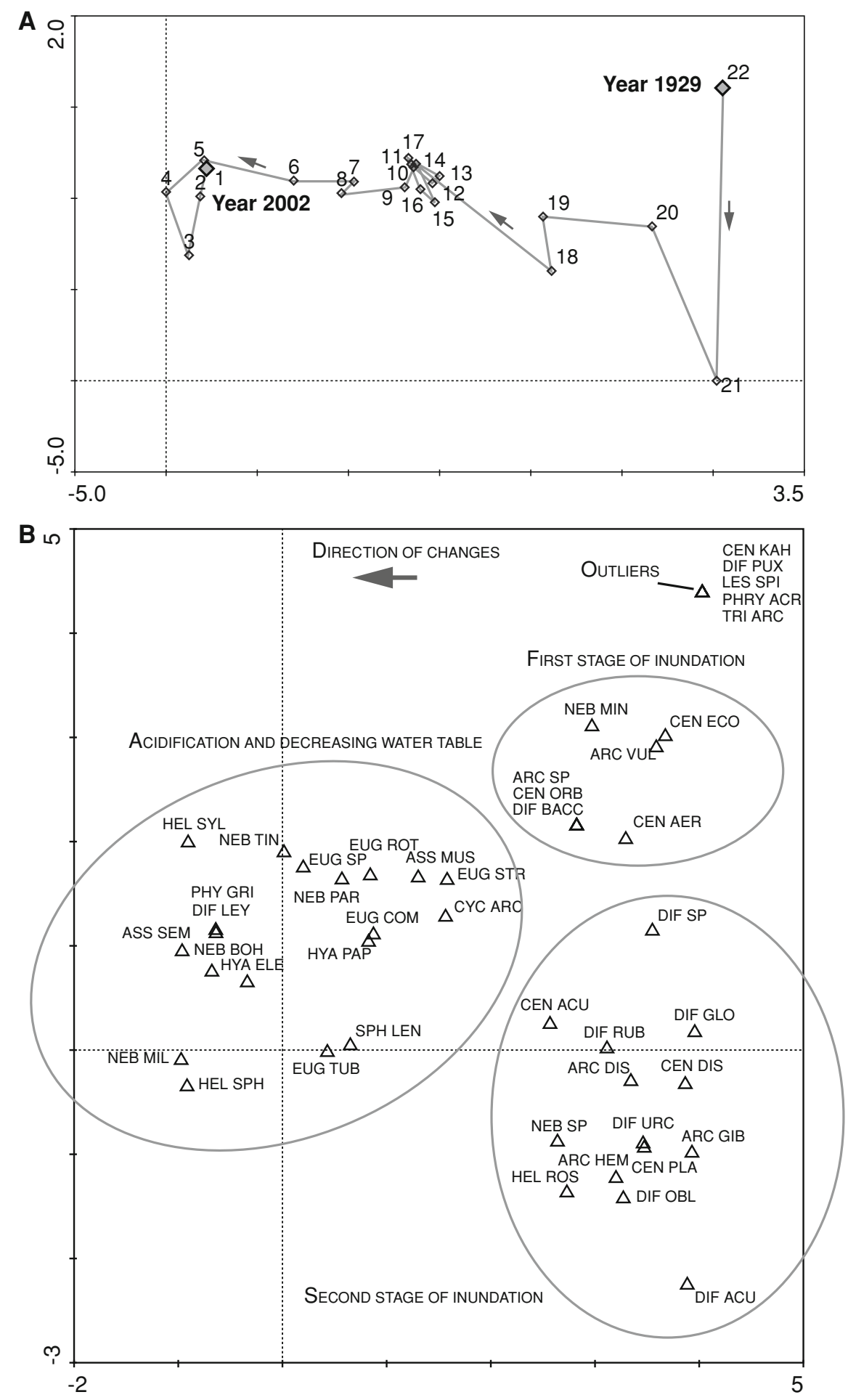
Fig. 6 Detrended correspondence analysis (DCA) plot. a samples: grey line follows the samples from the bottom to top of the monolith, grey arrows show direction of changes; $\mathbf{b}$ species: particular stages of the succession are marked, grey arrow shows direction of changes. Explanation of species names: ARC CAT Arcella catinus, ARC DIS A. discoides, ARC GIB A. gibbosa, ARC HEM A. hemispherica, ARC SP A. sp., ARC VUL A. vulgaris, ASS MUS Assulina muscorum, ASS SEM A. seminulum, CEN ACU Centropyxis aculeata, CEN AER C. aerophila, CEN DIS $C$. discoides, CEN ECO $C$. ecornic, CEN KAH C. kahlii, CEN PLA C. platystoma, CEN ORB C. orbicularis, CYC ARC Cyclopyxis arcelloides, DIF ACU Difflugia acuminata, DIF BACC D. baccilifera, DIF GLO D. globulosa, DIF LEY D. leidyi, DIF OBL D. oblonga, DIF PUX D. pulex, DIF RUB D. rubescens, DIF URC $D$. urceolata, DIF SP D. sp., EUG COM Euglypha compressa, EUG ROT E. rotunda, EUG SP E. sp., EUG STR E. strigosa, EUG TUB E. tuberculata, HEL ROS Heleopera rosea, HEL SPH H. sphagnii, HEL SYL $H$. sylvatica, HYA ELE Hyalosphenia elegans, HYA PAP $H$. papilio, LES SPI Lesquereusia spiralis, NEB BOH Nebela bohemica, NEB MIL $N$. militaris, NEB MIN $N$. minor, NEB PAR $N$. parvula, NEB SP $N$. sp., NEB TIN $N$. tincta, PHY GRI Physochila (Nebela) griseola, PHRY ACR Phryganella acropodia, SPH LEN Sphenoderia lenta, TRI ARC Trigonopyxis arcula
Both local vegetation and protozoa responded very rapidly to the inundation. Protozoa (testate amoebae), however, better reflect the particular stages of floating mat development. The bottom $10 \mathrm{~cm}$ was part of the floating mat, immersed in the water gap. Surprisingly, desmids were very well preserved. Aquatic and telmatic vegetation disappeared along with Sphagnum expansion. However, desmids existed up to $22 \mathrm{~cm}$, indicating a very high water table. Testate amoebae communities tracked this rapid shift well, with a change from a Centropyxis aculeata-Difflugia rubescens community to a Cyclopyxis arcelloidesHyalosphenia papilio assemblage. Zone Ma-ta-3 represents a stable $\mathrm{pH}$ and DWT. The DWT and $\mathrm{pH}$ values inferred from testate amoebae are negatively correlated (Fig. 7), which suggests some minerotrophic influence, probably groundwater input. The Mukrza peatland records acidification above $36 \mathrm{~cm}$, and it can be classified as a poor fen on the basis of vegetation and $\mathrm{pH}$. The last stage (zone MA-ta-4) is associated with a lower water table, indicated by "dry" indicators such as Nebela militaris, Nebela
Fig. 7 Scatter plot of $\mathrm{pH}$ versus DWT with box plots characterizing each axis

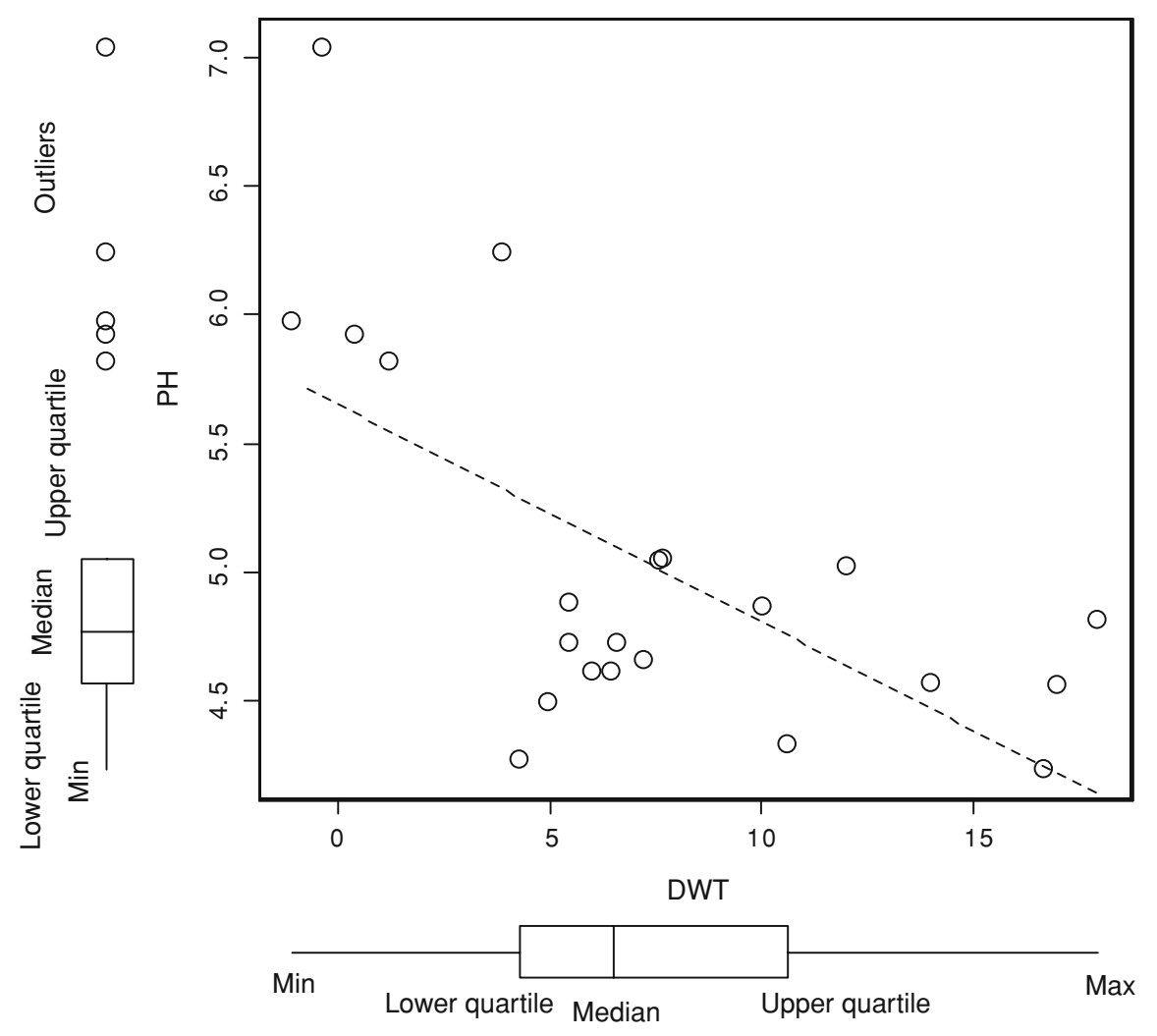


tincta and Assulina seminulum. Such a sequence of changes was also observed in another study from the Tuchola Forest (Lamentowicz et al. 2007).

\section{Palaeoecology and succession}

Testate amoebae are increasingly used in palaeoenvironmental studies of peatlands (Mitchell et al. 2008a, b). However, we still do not know exactly how rapidly new communities are established in newly created habitats (Wanner et al. 2008). In the case of the Mukrza mire, a complete environmental change occurred within 1 year after the dammed lake filled with water. Records from Mukrza can be seen as an example of a wet shift under simplified, anthropogenic conditions.

Hydrological conditions in European peatlands are dependent on precipitation and temperature, which influence evapotranspiration (Charman 2002). Reconstruction of the above-mentioned climatic variables is therefore very difficult. Using subfossil testate amoebae, we were able to reconstruct a water table deficit during the growing season (Charman 2007). In the case of Mukrza, we are certain that the water table was influenced by the reservoir and that peatland vegetation changes are anthropogenic. For that reason, we were able to observe how the testate amoebae community gradually adjusted to the habitat. Such a pattern was also observed in long, Holocene records in which kettle holes became peatlands. Once a peatland reaches the terrestrialization threshold, it may become sensitive to climatic change. The decrease in the water table in Mukrza in recent times (MA-ta-4) might be related to climatic change. Because this peatland is not ombrotrophic, changes may be caused by alterations in local hydrology. More records from several sites in the region are needed to test this notion. There are, however, examples of minerotrophic peatlands that are sensitive to climatic changes (Booth et al. 2004).

We established the indicator status of some testate amoebae species that had been previously recorded in peats, for instance, Difflugia urceolata, which was regarded as an indicator of flooding and eutrophication in a kettle hole mire in the Tuchola Forest (Lamentowicz et al. 2008c). In the Mukrza peatland, this species occurred in the first stage of inundation (Fig. 5, M-ta-1). This record supports our assumptions about the ecology of this species. Arcella discoides is another intriguing taxon recorded in this study. It is usually regarded as a wet indicator. However, it is also found together with dry indicators in peatland palaeoecological studies (Blundell and Barber 2005; van der Linden et al. 2008). Lamentowicz et al. (2009) suggested that it should be regarded as a sign of disturbance and hydrological instability, as it rapidly colonizes new environments. In the Mukrza profile, it occurred only at the beginning of the flooding. This record also supports our former observations (Lamentowicz et al. 2009). Nevertheless, A. discoides may have a different ecological tolerance in other geographic locations. The lack of Archerella flavum in the Mukrza peat archive is surprising. In northern and western Poland, A. flavum occurs mainly in wet and acid Sphagnum. Considering other published peat profiles (Lamentowicz et al. 2008b, 2009), we can assume that A. flavum needs very oligotrophic and stable hydrological conditions. Protists are distributed mainly via wind, waterfowl, and other migrating animals (Weisse 2008). A. flavum had $>50$ years to immigrate into the newly created Sphagnum carpet. A possible explanation for its absence could be a complete lack of populations in the vicinity of the peatland.

\section{Peatland management and human impact}

The damming of a river may lead to various effects in its catchment. A GIS study by Kowalewski (2001) showed that the building of the Koronowski Reservoir resulted in similar processes as those observed in our study. That reservoir was created in 1960. It is located in a similar sandy outwash plain. Kowalewski's research was based on aerial photographs and cartographic materials collected over time. He observed many hydrological consequences of the damming: (1) appearance of new water bodies and wetlands (resulting from paludification), (2) a rise in the water level of existing lakes, and (3) flooding of existing peatlands and their replacement by new water bodies. Such flooding was also observed in this study. Another effect described by Kowalewski was separation of the floating mats that previously were attached to the lakeshore. A similar process was observed around the Żur dam lake. The Żabicko kettle-hole lake (Fig. 1), located south of the Mukrza mire, has detached floating mats similar to those in the Koronowski Reservoir. We conclude that the same patterns 
probably occurred in areas adjacent to the Koronowski and Żur reservoirs. Unfortunately, no palaeoecological study has yet been done near the Koronowski Reservoir for comparison with our study. We found no similar study done anywhere in the world.

The pattern of succession in the Mukrza mire can be a useful reference for rewetted Sphagnum mires, where processes of peat accumulation re-appear. We obtained data on a recent disturbance that led to a positive effect on peat accumulation. However, the present condition cannot be regarded as the pristine state of the peatland. The pattern of changes in testate amoebae might be useful to assess the results of restoration in cut-over peatlands (Mitchell et al. 2008a, b). Our data might be used to define a stable testate amoebae community in Sphagnum. Analysis of testate amoebae seems to be a good alternative approach for assessing restoration processes, in contrast to labourintensive, repeated field measurements (LaggounDéfarge et al. 2008). Short-core studies, covering the last 50-100 years, on restored sites might be key for choosing the best strategy for conservation or restoration efforts. In peatland ecology, an historical perspective on the present protozoan communities may help to predict their future stability.

Acknowledgments This study was funded by a research grant from the Polish Ministry of Science and Higher Education (No. 2PO4G04929) (PI Milena Obremska). Mariusz Lamentowicz was funded by the above-mentioned grant as well as another grant from the Polish Ministry of Science and Higher Education (No. 2PO4G03228). We are indebted to Kazimierz Tobolski, and to Krystyna Milecka for inspiration and discussions. We thank David Wilkinson, Richard Payne and Mark Brenner for helpful remarks. We also thank Charlotte Vandenberghe and Sylwia Ufnalska for improving the English. Further funding to ML by Foundation for Polish Science (FNP) (Outgoing Fellowship KOLUMB) is acknowledged.

\section{References}

Amesbury MJ, Charman DJ, Fyfe RM, Langdon PG, West S (2008) Bronze Age upland settlement decline in southwest England: testing the climate change hypothesis. J Archaeol Sci 35:87-98. doi:10.1016/j.jas.2007.02.010

Appleby PG (2001) Chronostratigraphic techniques in recent sediments. In: Last WM, Smol JP (eds) Tracking environmental changes using lake sediments Vol 2: basin analysis, coring, and chronological techniques. Kluwer, Dordrecht, pp 171-203

Appleby PO, Shotyk W, Frankhauser A (1997) Lead-210 age dating of three peat cores in the Jura Mountains,
Switzerland. Water Air Soil Pollut 100:223-231. doi:10. 1023/A: 1018380922280

Belyea LR, Malmer N (2004) Carbon sequestration in peatland: patterns and mechanisms of response to climate change. Glob Change Biol 10:1043-1051

Berglund BE, Ralska-Jasiewiczowa M (1986) Pollen analysis and pollen diagrams. In: Berglund BE (ed) Handbook of Holocene paleoecology and paleohydrology. Wiley, Chichester, pp 455-484

Blundell A, Barber K (2005) A 2800-year palaeoclimatic record from Tore Hill Moss, Strathspey, Scotland: the need for a multi-proxy approach to peat-based climate reconstructions. Quat Sci Rev 24:1261-1277. doi:10.1016/j.quas cirev.2004.08.017

Blundell A, Charman DJ, Barber K (2008) Multiproxy late Holocene peat records from Ireland: towards a regional palaeoclimate curve. J Quat Sci 23:59-71. doi:10.1002/ jqs. 1115

Booth RK (2007) Testate amoebae as proxies for mean annual water-table depth in Sphagnum-dominated peatlands of North America. J Quat Sci 23:43-57. doi:10.1002/jqs. 1114

Booth RK, Jackson ST, Gray CED (2004) Paleoecology and high-resolution paleohydrology of a kettle peatland in upper Michigan. Quat Res 61:1-13. doi:10.1016/ j.yqres.2003.07.013

Booth RK, Sullivan ME, Sousa VA (2008) Ecology of testate amoebae in a North Carolina pocosin and their potential use as environmental and paleoenvironmental indicators. Ecoscience 15:277-289. doi:10.2980/15-2-3111

Charman DJ (2002) Peatlands and environmental change. Wiley, Chichester, $301 \mathrm{pp}$

Charman DJ (2007) Summer water deficit variability controls on peatland water-table changes: implications for Holocene palaeoclimate reconstructions. Holocene 17:217227. doi: $10.1177 / 0959683607075836$

Charman D, Blundell A (2007) A new European testate amoebae transfer function for palaeohydrological reconstruction on ombrotrophic peatlands. J Quat Sci 22:209221. doi: $10.1002 /$ jqs. 1026

Charman DJ, Hendon D, Woodland WA (2000) The identification of testate amoebae (Protozoa: Rhizopoda) in peats. Technical Guide No. 9. Quaternary Research Association, London, $147 \mathrm{pp}$

Charman D, Roe HM, Gerhels WR (2002) Modern distribution of saltmarsh testate amoebae: regional variability of zonation and response to environmental variables. J Quat Sci 17:387-409. doi:10.1002/jqs.703

Clarke KJ (2003) Guide to identification of soil protozoatestate amoebae. Freshwater Biological Association, Ambleside, $40 \mathrm{pp}$

Erdtman G, Berglund BE, Praglowski J (1961) An introduction to a Scandinavian pollen flora. Grana Palynol 2:3-92

Escobar J, Brenner M, Whitmore TJ, Kenney WF, Curtis JH (2008) Ecology of testate amoebae (thecamoebians) in subtropical Florida lakes. J Paleolimnol 40:715-731. doi:10.1007/s10933-008-9195-5

Faegri K, Iversen J (1989) Texbook of pollen analysis. Wiley, Chichester, $328 \mathrm{pp}$

Flynn WW (1968) The determination of low-levels of polonium-210 in environmental materials. Anal Chim Acta 43:221-227. doi:10.1016/S0003-2670(00)89210-7 
Gorham E, Rochefort L (2003) Peatland restoration: a brief assessment with special reference to Sphagnum bogs. Wetlands Ecol Manage 11:109-119. doi:10.1023/A:102 2065723511

Grimm EC (1987) CONISS: a Fortran 77 program for stratigraphically constrained cluster analysis by the method of incremental sum of squares. Comput Geosci 13:13-35. doi:10.1016/0098-3004(87)90022-7

Grimm EC (1992) TILIA/TILIA graph. Version 1.2. Illinois State Museum, Springfield

Grospietsch T (1958) Wechseltierchen (Rhizopoden). Kosmos, Stuttgart, $86 \mathrm{pp}$

Heathwaite AL, Göttlich K (eds) (1993) Mires. Process, exploitation and conservation. John Wiley, Chichester, $506 \mathrm{pp}$

Hendon D, Charman DJ (1997) The preparation of testate amoebae (Protozoa: Rhizopoda) samples from peat. Holocene 7:199-205. doi:10.1177/095968369700700207

Hendon D, Charman D, Kent M (2001) Palaeohydrological records derived from testate amoebae analysis from peatlands in northern England: within-site variability, between-site comparability and palaeoclimatic implications. Holocene 11:127-148. doi:10.1191/095968301674 575645

Jankovská V, Komárek J (2000) Indicative value of Pediastrum and other coccal green algae in palaeoecology. Folia Geobot 35:59-82. doi:10.1007/BF02803087

Joosten H, Clarke D (2002) Wise use of mires and peatlandsbackground and principles including a framework for decision-making. International Mire Conservation Group and International Peat Society, Saarijärvi, $304 \mathrm{pp}$

Juggins S (2003) C2 user guide. Software for ecological and palaeoecological data analysis and visualisation. University of Newcastle, Newcastle upon Tyne, $69 \mathrm{pp}$

Komárek J, Jankovská V (2001) Review of the green algal genus Pediastrum; implication for pollen-analytical research. Bibl Phycol 108:1-127

Kowalewski G (2001) Transformation of wetlands and lakes at the zone of influence of Koronowski Reservoir. Limnol Rev 1:165-172

Kowalewski G (2003) Przeobrażenia jezior i mokradeł w strefie oddziaływania Zbiornika Koronowskiego. Bogucki Wydawnictwo Naukowe, Poznań, 62 pp

Laggoun-Défarge F, Mitchell E, Gilbert D, Disnar JR, Comont L, Warner BG, Buttler A (2008) Cut-over peatland regeneration assessment using organic matter and microbial indicators (bacteria and testate amoebae). J Appl Ecol 45:716-727. doi:10.1111/j.1365-2664.2007.01436.x

Lamentowicz M, Mitchell EAD (2005a) The ecology of testate amoebae (Protists) in Sphagnum in north-western Poland in relation to peatland ecology. Microb Ecol 50:48-63. doi:10.1007/s00248-004-0105-8

Lamentowicz M, Mitchell EAD (2005b) Testate amoebae (Protists) as palaeoenvironmental indicators in peatlands. Pol Geol Inst Spec Pap 16:58-64

Lamentowicz M, Tobolski K, Mitchell EAD (2007) Palaeoecological evidence for anthropogenic acidification of a kettle-hole peatland in northern Poland. Holocene 17:1185-1196. doi:10.1177/0959683607085123

Lamentowicz Ł, Lamentowicz M, Gąbka M (2008a) Testate amoebae ecology and a local transfer function from a peatland in western Poland. Wetlands 28:164-175. doi:10.1672/07-92.1

Lamentowicz M, Cedro A, Miotk-Szpiganowicz G, Mitchell EAD, Pawlyta J, Goslar T (2008b) Last millennium palaeoenvironmental changes from a Baltic bog (Poland) inferred from stable isotopes, pollen, plant macrofossils and testate amoebae. Palaeogeogr Palaeoclimatol Palaeoecol 265:93-106. doi:10.1016/j.palaeo.2008.04.023

Lamentowicz M, Obremska M, Mitchell EAD (2008c) Autogenic succession, land-use change, and climatic influences on the Holocene development of a kettle hole mire in Northern Poland (Northern Poland). Rev Palaeobot Palynol 151:21-40. doi:10.1016/j.revpalbo.2008.01.009

Lamentowicz M, Milecka K, Gałka M, Cedro A, Pawlyta J, Piotrowska N, Lamentowicz Ł, van der Knaap WO (2009) Climate- and human-induced hydrological change since AD 800 in an ombrotrophic mire in Pomerania (N Poland) tracked by testate amoebae, macro-fossils, pollen, and tree-rings of pine. Boreas 38:214-229. doi:10.1111/ j.1502-3885.2008.00047.x

Langdon PG, Barber KE (2005) The climate of Scotland over the last 5000 years inferred from multiproxy peatland records: inter-site correlations and regional variability. J Quat Sci 20:549-566. doi:10.1002/jqs.934

Mauquoy D, Engelkes T, Groot MHM, Markesteijn F, Oudejans MG, van der Plicht J, van Geel B (2002) High-resolution records of late-Holocene climate change and carbon accumulation in north-west European ombrotrophic peat bogs. Palaeogeogr Palaeoclimatol Palaeoecol 186:275-310. doi:10.1016/S0031-0182(02)00513-8

Mitchell E, Charman D, Warner B (2008a) Testate amoebae analysis in ecological and paleoecological studies of wetlands: past, present and future. Biodivers Conserv 17:2115-2137. doi:10.1007/s10531-007-9221-3

Mitchell EAD, Payne RJ, Lamentowicz M (2008b) Potential implications of differential preservation of testate amoebae shells for paleoenvironmental reconstruction in peatland. $\mathrm{J}$ Paleolimnol 40:603-618. doi:10.1007/s10933-007-9185-z

Moore PD, Webb JA, Collinson ME (1991) Pollen analysis. Blackwell Scientific Publication, Oxford, $216 \mathrm{pp}$

Ogden CGR, Hedley H (1980) An atlas of freshwater testate amoebae. British Museum (Natural History) and Oxford University Press (London and Oxford), London, 222 pp

Payne RJ, Mitchell EAD (2007) Ecology of testate amoebae from mires in the Central Rhodope Mountains, Greece and development of a transfer function for palaeohydrological reconstruction. Protist 158:159-171. doi:10.1016/ j.protis.2006.11.003

Payne RJ, Pates JM (2009) Vertical stratification of testate amoebae in the Elatia Mires, northern Greece: palaeoecological evidence for a wetland response to recent climatic change, or autogenic processes? Wetlands Ecol Manage. doi:10.1007/s11273-008-9112-8

R Development Core Team (2006) R: A language and environment for statistical computing. $\mathrm{R}$ Foundation for Statistical Computing. URL http://www.R-project.org., Vienna, Austria

Roos-Barraclough F, van der Knaap WO, van Leeuwen JFN, Shotyk W (2004) A Late-glacial and Holocene record of climatic change from a Swiss peat humification profile. Holocene 14:7-19. doi:10.1191/0959683604hl685rp 
Rydin H, Jeglum J (2006) The biology of peatlands. Oxford University Press, Oxford, 343 pp

Shotyk W, Cheburkin AK, Appleby PG, Frankhauser A, Kramers JD (1996) Two thousand on atmospheric arsenic, antimony, and lead deposition recorded in an ombrotrophic peat bog profile, Jura Mountains. Earth Planet Sci Lett 145:E1-E7. doi:10.1016/S0012-821X(96)00197-5

Sillasoo Ü, Mauquoy D, Blundell A, Charman D, Blaauw M, Daniell JRG, Toms P, Newberry J, Chambers FM, Karofeld E (2007) Peat multi-proxy data from Männikjärve bog as indicators of late Holocene climate changes in Estonia. Boreas 36:20-37. doi:10.1080/03009480600923360

ter Braak CJF, Šmilauer P (1998) CANOCO reference manual and user's guide to Canoco for windows software for Canonical community ordination (version 4). Centre for Biometry, Wageningen, $352 \mathrm{pp}$

Tobolski K (2003) Torfowiska, na przykładzie Ziemi Świeckiej (Peatlands-an example of Świecie area). Towarzystwo Przyjaciół Dolnej Wisły, Świecie, 255 pp (in Polish)

Turetsky MR, Manning SW, Wieder RK (2004) Dating recent peat deposits. Wetlands 24:324-356. doi:10.1672/02775212(2004)024[0324:DRPD]2.0.CO;2 van der Linden M, Vickery E, Charman DJ, van Geel B (2008) Effects of human impact and climate change during the last 350 years recorded in a Swedish raised bog deposit. Palaeogeogr Palaeoclimatol Palaeoecol 262:1-31. doi:10. 1016/j.palaeo.2008.01.018

Wanner M, Elmer M, Kazda M, Xylander WER (2008) Community assembly of terrestrial testate amoebae: How is the very first beginning characterized? Microb Ecol 56:43-54. doi:10.1007/s00248-007-9322-2

Weisse T (2008) Distribution and diversity of aquatic protists: an evolutionary and ecological perspective. Biodivers Conserv 17:243-259. doi:10.1007/s10531-007-9249-4

Weltzin JF, Harth C, Bridgham SD, Pastor J, Vonderharr M (2001) Production and microtopography of bog bryophytes: response to warming and water-table manipulations. Oecologia 128:557-565. doi:10.1007/s004420100691

Wilmshurst JM, McGlone M, Charman DJ (2002) Holocene vegetation and climate change in southern New Zealand: linkages between forest composition and quantitative surface moisture reconstructions from an ombrotrophic bog. J Quat Sci 17:653-666. doi:10.1002/jqs.689 